\title{
Pathophysiology of the aging kidney and therapeutic interventions
}

\author{
Keizo Kanasaki, Munehiro Kitada and Daisuke Koya
}

Kidneys are among the organs affected by the aging process. Aging kidneys are characterized by progressive scarring and measurable declines in renal function. Deficiencies in renal function are associated with mortality in all populations. Therefore, if the kidneys age at an accelerated rate relative to the other organs in a particular individual, then slowing or reversing the kidney aging process may be a therapeutically useful strategy. In this review, we will discuss the physiology and pathogenesis of kidney aging and analyze potential therapeutic strategies for halting the aging process in the kidneys.

Hypertension Research (2012) 35, 1121-1128; doi:10.1038/hr.2012.159; published online 18 October 2012

Keywords: fibrosis; Klotho; RAS; senescence; sirtuins

\section{INTRODUCTION}

Aging is a constant and predictable sequence of events involving the growth and development of living organisms. Evolutionary Biology of Aging defines aging as 'a persistent decline in the age-specific fitness components of an organism due to internal physiological deterioration'. Although aging is the consequence of 'internal physiological deteriorations', aging in humans is recognized as a multidimensional process encompassing physical, psychological and social alterations. For example, exercise capacity and reaction times diminish with age, whereas knowledge, experience and wisdom can be gained.

Aging is associated with a decline in physiological homeostasis. It is likely that aging-associated declines in organ function are not a homogenous sequence but represent a multidimensional process, as described above. In higher organisms, aging homeostasis is regulated by the interaction of multiple organs; age-mediated dysfunction in one organ can lead to a functional deficiency in multiple organs. The organs of an individual exhibit different rates of aging, which are influenced by several modifiable factors, including genetics, lifestyle choices and environmental exposures.

The kidneys are also affected by the aging process, which results in numerous effects on the renal system. ${ }^{2}$ Renal mass decreases between the ages of 30 and 80 years, with the steepest decline observed after age $50 .{ }^{3,4}$ Fat and fibrosis scarring may replace some of the remaining functional parenchymal tissue. ${ }^{4-6}$ This scarring and loss of kidney parenchymal tissue occurs primarily in the renal cortex; ${ }^{6}$ therefore, scarring affects the nephrons that are important for maximal urine concentration. Even in normal aging kidneys, 30\% of the glomeruli are destroyed and display diffuse glomerular sclerosis by age $75,{ }^{7}$ and the remaining glomeruli exhibit impaired filtering ability. The results from aging studies in animals and humans suggest that diverse factors may contribute to the scarring process, such as tissue ischemia, injury, hypertension, metabolic defects and obesity.

Aging is an unavoidable process of life for all living creatures. However, the evidence from longitudinal studies suggests that one-third of all healthy individuals aged 23-97 years are essentially unaffected by changes in renal function throughout their lives. ${ }^{8}$ Recent evidence reveals that several anti-aging molecules are active in the human body and that these molecules are regulated by multiple factors through individual behaviors. ${ }^{9,10}$ These results indicate that kidney aging could in fact be delayed and even reversed with the appropriate intervention.

In this review, we will discuss the general characteristics of renal aging and analyze potential interventional methods for aging kidneys.

\section{PHYSIOLOGY OF AGED KIDNEYS}

At baseline, healthy normotensive older men exhibit $40 \%$ less renal plasma blood flow than young men. ${ }^{11}$ In older men, glomerular filtration is maintained and the filtration fraction is elevated ${ }^{12}$ by (1) enhanced hyperfiltration of the residual glomeruli by constriction of the efferent arteriole in comparison with the afferent arteriole ${ }^{13}$ and (2) a relative increase in the medullary blood flow due to a reduction in renal plasma blood flow in the renal cortex. ${ }^{3}$ Hyperfiltration in the glomeruli of the aging kidney can result in glomerulosclerosis by increasing intraglomerular pressure.

Aging kidneys exhibit increased vulnerability to stressful conditions and adrenergic activation. ${ }^{14}$ Under conditions of stress or illness associated with a reduction in the effective circulating volume, such as heart failure or dehydration, the levels of vasoconstrictive substances are markedly increased. ${ }^{15}$ Such vasoconstrictive substances in the elderly may further reduce the already compromised blood flow in the aging kidney. ${ }^{15}$ Under such conditions, renal circulation is highly 
dependent on the vasodilatory prostaglandins that can modulate excess vasoconstriction. ${ }^{15}$ The importance of prostaglandins in adrenergic activation has been demonstrated in experimental animal models. ${ }^{16}$ The function of aging kidneys can be preserved through vasodilation to compensate for the loss of vasculature, ${ }^{11,17}$ because such a treatment can impair the renal response to maximal vasodilation. ${ }^{10}$ This prostaglandin-dependent homeostasis in the aging kidney is likely one of the reasons why older individuals exhibit a higher risk of non-steroidal anti-inflammatory drug-induced renal injury. ${ }^{18,19}$ Some reports state that the inability of dopamine to affect creatinine clearance in the elderly may be responsible for the inability to respond to endogenous dopamine during times of physiologic stress, thereby resulting in an increased susceptibility to renal deficiency. ${ }^{20}$ How this dopamine insensitivity relates to the vasodilatory prostaglandin systems is unclear.

\section{NEPHRON FUNCTION}

In general, the glomerular filtration rate in humans starts to decline by approximately $1 \mathrm{ml}$ per year after approximately 30 years of age. ${ }^{21}$ By the time they reach 90 years of age, humans exhibit an inulin clearance rate of approximately $65 \mathrm{ml} \mathrm{min}^{-1} .{ }^{21}$ Creatinine clearance also decreases with age $\left(7.5-10 \mathrm{ml} \mathrm{min}^{-1}\right.$ per decade), although significant variability exists in the reported age-related decline in renal function in longitudinal studies; ${ }^{8}$ approximately one-third of patients exhibit no change in the glomerular filtration rate, another third exhibit a slight decline and the remaining third exhibit a more marked decline. ${ }^{8}$ In the elderly, the production of creatinine also decreases with age, whereas the secretion of creatinine from the tubules increases. ${ }^{22}$ Therefore, although the glomerular filtration rate declines in aging kidneys, the serum creatinine levels may remain stable, ${ }^{23}$ which further highlights the limitation of using relative insensitive serum creatinine levels as a marker of renal function.

In general, electrolyte and fluid homeostasis is relatively well maintained during normal aging. In a steady-state condition, older individuals can maintain balanced sodium levels. However, under stressful conditions, the ability to maximally dilute the urine is impaired, and the excreted water load is compromised. ${ }^{24}$ For instance, aging kidneys exhibit a significant impairment in the reduction of urinary sodium excretion in response to dietary sodium chloride deprivation compared with young individuals. ${ }^{24}$ The mean lithium clearance, an indicator of proximal tubular function, is significantly decreased in older individuals when compared with healthy, young individuals. ${ }^{25}$ In the elderly, the fractional proximal sodium reabsorption is significantly higher than it is in young individuals, but this elevation is offset by the lower distal fractional reabsorption of sodium.

In contrast, potassium handling in aging kidneys is negatively affected by aging. Older individuals are susceptible to developing hyperkalemia when using certain drugs, such as inhibitors of the renin-angiotensin system. Urine potassium is derived from active transtubular transport in the distal nephron and collecting duct, and is associated with the reabsorption of sodium by the aldosteronemodulated Na-K ATPase transporters. Impaired potassium secretion, which is directly associated with disorders in sodium reabsorption, may occur in aging kidneys due to tubular atrophy and tubular interstitial scarring. Hyporeninemic or normoreninemic hypoaldosteronism and volume depletion-related suppression of water and sodium delivery into the distal nephron is also associated with potassium secretion disorders in aging kidneys. ${ }^{26}$ This tubular dysfunction results in the inability to maximally concentrate and dilute the urine; older individuals may exhibit a higher rate of nocturia and a predisposition to dehydration and volume-dependent hyper- or hyponatremia. ${ }^{27,28}$

One of the clinically important issues in aging kidneys is the increased susceptibility to drug-induced nephrotoxicity. ${ }^{29}$ In older individuals, the metabolism and clearance of administered drugs are compromised due to the decline in hepatic metabolism and the reduction in the excretory capacity of the kidneys. Therefore, aging kidneys often suffer from the effects of sustained elevated concentrations of drugs because of the altered pharmacokinetics of these drugs. Drug pharmacodynamics are also altered in older individuals through the modulation of drug sensitivity and the physiological response to drug actions, regardless of changes in kidney condition. The combination of altered pharmacodynamics and pharmacokinetics in older individuals with multiple comorbidities that require medication results in an increased probability of drug toxicities and associated complications. It is therefore reasonable to start therapy at the lowest drug dosage required and gradually increase the dose over time.

Other important functional alterations in the kidneys include a deficiency in urine acidification and acid excretion. The ability of aging kidneys to recover from acute damage is also compromised, ${ }^{30-32}$ and they are vulnerable to ischemic damage, exhibiting increased apoptosis following ischemic damage. ${ }^{32}$ In addition, the tubular cells of aging kidneys exhibit disorders in their ability to repopulate following acute ischemic damage. ${ }^{32}$

\section{ENDOCRINE FUNCTION}

The reduction in renal function is associated with the decreased production of erythropoietin (EPO), ${ }^{33}$ resulting in an increased incidence of anemia. ${ }^{34}$ Healthy elderly individuals exhibit relatively high serum EPO levels, which suggests a compensatory response to age-related subclinical blood loss, increased erythrocyte turnover or increased EPO resistance. ${ }^{35}$ EPO levels are, however, unexpectedly suppressed in anemic elderly patients when compared with anemic young individuals, which suggests a blunted response to low hemoglobin levels. ${ }^{36-38}$

Older women with osteoporosis and mild renal dysfunction exhibit lower calcium absorption rates and lower serum 1,25-dihydroxyvitamin D levels despite normal serum 25-hydroxyvitamin D levels, indicating a deficiency in the conversion of 25-hydroxyvitamin D to 1,25-dihydroxyvitamin $\mathrm{D}$ by the aging kidneys. ${ }^{39}$ Mild renal dysfunction (creatinine clearance less than $65 \mathrm{ml} \mathrm{min}^{-1}$ ) is an independent risk factor for falls and their associated fractures in older patients with osteoporosis. ${ }^{40}$ Calcitriol therapy has been shown to reduce the number of falls in elderly patients by $50 \%$, perhaps due to the increase in serum 1,25-dihydroxyvitamin $\mathrm{D}$ levels with the upregulation of vitamin $\mathrm{D}$ receptors in muscle tissue, resulting in improved muscle strength. ${ }^{39}$

Approximately $50 \%$ of insulin in the peripheral circulation is removed by the kidneys. ${ }^{41}$ The kidneys filter insulin from the glomeruli, after which it is taken up in the proximal tubules and subsequently degraded. Renal function deficiencies in older individuals result in reduced insulin clearance. These renal dysfunction-associated insulin clearance disorders are partially offset by diminished glucose tolerance secondary to age-induced defective insulin secretion and action. Chronic renal insufficiency-associated parathyroid hormone excess has been shown to result in impaired insulin secretion and impaired glucose tolerance in humans. ${ }^{42}$ Similarly, an analysis in an experimental animal model suggested that impaired insulin secretion in aging rats might be the result of aging-associated chronic renal insufficiency and excess parathyroid 
hormone. ${ }^{43}$ Glucose intolerance in healthy older patients is due to a decrease in both insulin secretion and insulin resistance. ${ }^{44}$ Therefore, even though the total body insulin clearance in older individuals is generally compromised when compared with younger individuals, older patients are at a higher risk of glucose intolerance. In addition, this lower insulin clearance rate may be a serious problem and present a higher risk of sustained hypoglycemia in older diabetic patients who are treated with hypoglycemic agents.

The sympathetic nervous system is also affected by the aging kidneys and exhibits enhanced activity in patients with chronic kidney disease, ${ }^{45}$ which can persist even after transplantation. ${ }^{46}$ Chronic activation of the sympathetic nervous system may also contribute to arterial stiffening with advanced arterial disease. Older individuals may also exhibit arterial stiffening, which is probably associated with the deterioration in their renal function. It is therefore reasonable to assume that the enhanced sympathetic tone associated with declining glomerular filtration rates and other factors may contribute to the vascular pathologies in elderly patients.

\section{PATHOLOGICAL CHANGES IN AGED KIDNEYS}

The weight of the kidneys progressively declines after the fifth decade of life. ${ }^{47}$ Renal cortical lesions become thinner, whereas the medulla remains relatively unaltered by aging. ${ }^{47}$ Although kidney weight declines with age, there is no evidence of an age-dependent decline in kidney volume when analyzed by computed tomography; imaging analyses demonstrate that the kidney parenchymal volume remains unaltered. ${ }^{48-50}$ The reason for the unaltered kidney volume in the elderly despite age-related glomerulosclerosis ${ }^{51}$ may be the compensatory hypertrophy of unaffected nephrons in response to the significant nephron loss caused by glomerulosclerosis and tubular atrophy. ${ }^{4}$ Studies have reported both increased volume in the functional glomeruli and decreased glomerular density in aging kidneys. ${ }^{52-55}$

The pathological characteristics of aging kidneys include glomerular sclerosis, tubular atrophy and tubulointerstitial fibrosis. ${ }^{51}$

In aging kidney glomerulus, hyaline mesangial matrix expansion results in the obliteration of the glomerular capillary loops ${ }^{56,57}$ and is associated with capillary tuft collapse and intra-capsular fibrosis. Different cell types within the glomeruli are also affected by aging. Aging-related glomerular enlargement is associated with significant mesangial expansion. ${ }^{58}$ Glomerular mesangial cells and endothelial cells increase in number till age $50,{ }^{59}$ thereby maintaining the ratio of the number of glomerular mesangial cells to the enlarged glomerular volume, suggesting a physiologically appropriate increase. After age 50, both mesangial cells and endothelial cell exhibited decreased trend and it become significant after age $70 .{ }^{59}$ On the other hand, podocytes do not increase despite the significant enlargement of the glomeruli, resulting in a relative depletion of podocytes. ${ }^{59}$ Podocytes exhibit hypertrophy in association with glomerular hypertrophy. ${ }^{60}$ Electron microscopy analysis reveals that podocyte injury with features such as hypertrophy, intracellular uptake of protein/absorptive droplets, foot process fusion and detachment of the podocytes from the glomerular basement membranes. ${ }^{57,61}$

It is thought that age-related fibrointimal hyperplasia in the small arteries leads to glomerulosclerosis and the subsequent initiation of associated local tubular atrophy and interstitial fibrosis. ${ }^{62}$ The presence of underlying diseases, such as hypertension and diabetes, may accelerate the pathological alterations observed in aging kidneys. ${ }^{2}$ The intimal hyperplasia in the interlobular arteries may allow for the transmission of abnormal arterial pulse waves into the smaller distal branches. ${ }^{63,64}$ These arterial pulse waves can lead to hyaline changes in the arterioles, resulting in an acceleration of the intimal fibrosis. ${ }^{63,64}$ Aging kidneys exhibit an elevated number of aglomerular arteries, which are characterized by directly connected arteries that bypass the afferent and efferent arterioles due to the loss of the glomeruli. ${ }^{62}$ In aging kidneys, tubular diverticula are often observed and are a probable source of renal cysts. ${ }^{65,66}$ These aging-related pathological alterations in the glomeruli and tubulointerstitium are not specific to aging kidneys but are also common pathways of kidney fibrosis in a number of renal diseases.

Vascular defects in aging kidneys are associated with renal parenchymal hypoxia and altered responses to hypoxia. The degree of hypoxia is positively associated with age-related tubulointerstitial injury. ${ }^{67}$ Tissue hypoxia induces the accumulation of hypoxiainducible factors (HIFs) ${ }^{68}$ master regulators of oxygen tension in tissues by the regulation of hypoxia-responsive genes such as vascular endothelial growth factor and EPO. ${ }^{68}$ Some reports indicate that the activation of HIFs may protect aging kidneys from kidney hypoxia. ${ }^{69}$ However, this relationship is undoubtedly complex, as renal tubulespecific knockout of von Hippel-Lindau tumor suppressor protein (VHL), which acts as an ubiquitin ligase to promote proteolysis of HIF- $1 \alpha,{ }^{70}$ induces severe fibrosis when compared with control littermates. ${ }^{71}$ VHL is not specific for HIF, and it is possible that HIF-independent effects stimulate renal fibrosis, whereas mice with HIF- $1 \alpha$ deletion in the kidney tubules also exhibit amelioration of kidney fibrosis in a unilateral ureteral obstruction model. ${ }^{72}$ Knockout mice studies ${ }^{71,72}$ are not performed in an aging-associated kidney disease model, but the altered regulation of HIFs in the aging kidney could be considered for potential interventions.

\section{COMBATING RENAL AGING}

Numerous metabolic, physiological and pathological factors contribute to the pathogenesis of kidney aging. Repeated tissue inflammation is one such factor involved in the kidney aging process. ${ }^{73}$ Underlying disease conditions are important therapeutic targets for the prevention of kidney aging. ${ }^{73}$ In addition to these established risk factors and interventions targeting them, such as renin-angiotensin system blockade, we will discuss kidney aging-associated molecules and potential methods for combating kidney aging (Figure 1).

\section{CALORIE RESTRICTION AND ACTIVATION OF SIRTUINS}

Calorie restriction consists of established dietary interventions that have been shown to increase both the median and maximum lifespan of a variety of species, including yeast, fish and mammals., ${ }^{9,74}$ The health benefits of calorie restriction have also been demonstrated in primates; calorie restriction in rhesus monkeys blunts aging and significantly delays the onset of age-related disorders, including cancer, diabetes, cardiovascular disease and brain atrophy. ${ }^{75}$

Numerous molecules may mediate the beneficial effects of calorie restriction. Among these calorie restriction-mediated molecules, sirtuin 1 (SIRT1) has a well-established importance in calorie restriction-mediated signaling. ${ }^{76}$ Calorie restriction likely enhances SIRT1 activity in most tissues, including the kidneys. ${ }^{77,78}$ In support of this finding, in SIRT1 knockout mice, the beneficial effects of calorie restriction are diminished. ${ }^{78}$ SIRT1 transgenic mice display a similar phenotype in response to calorie restriction. ${ }^{79}$ The potential SIRT1 activator, resveratrol, may induce a similar transcriptional profile to that of calorie restriction and provide protection against glomerulosclerosis. ${ }^{80-82}$ The significance of resveratrol dependence on SIRT1 activation in the renoprotection is, however, controversial. ${ }^{83}$ Calorie restriction-induced SIRT1 enhances forkhead box protein O 3 (FoxO3) deacetylation and the subsequent upregulation of Bnip3. 


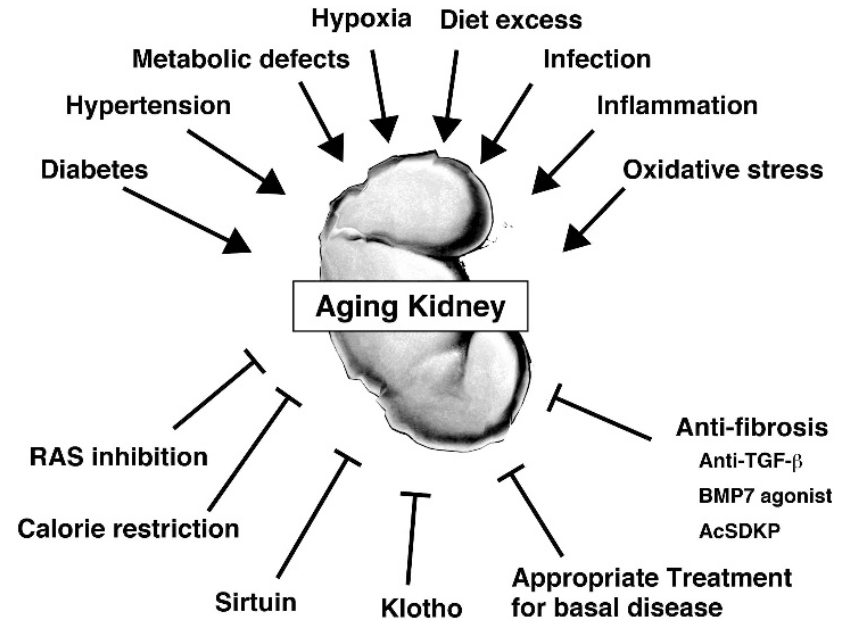

Figure 1 Working hypothesis of combating aging kidney. The kidney continuously suffers from various physiological/pathological stresses/toxins, and several such factors could accelerate kidney aging. In addition to the appropriate treatments for underlying diseases and the inhibition of aging accelerating factors, recent advances in geriatrics and the discovery of novel molecular targets revealed potential interventional clues for the aging kidney. In addition, anti-fibrosis therapies could be beneficial interventions for the aging kidney.

FoxO3 and Bnip3 activation induces autophagy in the renal proximal tubular cells and mitochondria biogenesis. ${ }^{78}$ SIRT1 also deacetylates HIF- $2 \alpha$ and has an important role in EPO production, which suggests that SIRT1 may act as a critical modulator of systemic oxygen levels and local oxygen tension. ${ }^{84}$ SIRT1 stimulates the activity of the liver-X receptor (LXR) ${ }^{85}$ and the farnesoid X receptor (FXR) ${ }^{86}$ both of which regulate lipid metabolism. ${ }^{85,86}$ SIRT1 activated-LXR and -FXR play preventative roles in the onset and progression of proteinuria and glomerulosclerosis in type 2 diabetes and diet-induced obesity in animal models. ${ }^{87-90}$ Although the beneficial effects of calorie restriction and SIRT1 activation on halting kidney aging and expanding longevity has not yet been reported in humans, the above evidence indicates that calorie restriction and/or SIRT1 activation may provide a potential clue to combat kidney aging.

\section{KLOTHO}

The Klotho gene encodes a transmembrane protein and is expressed primarily in the kidney. ${ }^{10}$ In 1997, Kuro-o et al. ${ }^{10}$ reported that mutations in the Klotho gene in mice resulted in multiple phenotypes of human aging, such as the calcification of soft tissue and vascular walls, hyperphosphatemia, muscle and skin atrophy, and early death. Furthermore, Klotho gene overexpression in mice has been shown to extend life span when compared with control mice. ${ }^{10,91}$ The Klotho gene has vital roles in the regulation of both phosphorus and calcium phosphate transport. ${ }^{92}$ Membrane-bound Klotho functions as the obligate coreceptor for fibroblast growth factor (FGF) 23, and any defects in the function of either Klotho or FGF23 in mice lead to phosphate accumulation and premature aging. ${ }^{93}$ Patients with CKD eventually suffer premature death not from renal failure but as a result of the early onset of common aging-related diseases, such as cardiovascular disease and diabetes. ${ }^{94}$ CKD patients exhibit remarkable declines in the kidney expression of Klotho, ${ }^{95}$ which is associated with resistance to FGF23, ${ }^{96}$ hyperphosphatemia and vascular calcification, symptoms similar to those of Klotho-deficient mice. ${ }^{10,91}$ These data suggest a significant link between phosphate metabolism and kidney aging. Thus, Klotho deficiency may be a candidate therapeutic target for kidney aging. ${ }^{95}$

\section{PERSPECTIVE: ANTI-FIBROSIS THERAPY}

Similar to the advanced features in all progressive kidney diseases, the pathological hallmarks of aging kidneys include fibroproliferative changes, such as glomerulosclerosis and tubulointerstitial fibrosis. Therefore, if an anti-fibrosis therapy were available, it could be an effective therapy for aging kidneys and their associated health problems.

The role of transforming growth factor (TGF)- $\beta$ in kidney fibrosis is well established. ${ }^{97}$ TGF- $\beta$ induces the intracellular signaling molecules specific to the TGF- $\beta$ family, smads. ${ }^{98-100}$ Smads are subclassified into three types: (1) receptor-regulated smads or R-smads ( $\operatorname{smad} 2$ and 3$)$; (2) common smads or co-smad $(\operatorname{smad} 4)$; and (3) inhibitory smads or I-smads ( $\operatorname{smad} 6$ and 7 ). During TGF- $\beta$ binding, the phosphorylated type I receptor recruits R-smads for phosphorylation, and phosphorylated R-smads interact with the co-smad in the cell cytoplasm. The smad heterodimer binds to smad-binding elements in the DNA promoter regions. Unlike the other smads, I-smad competitively inhibits R-smad phosphorylation by the type I receptor. ${ }^{101}$ Therefore, when examining the biology of the profibrotic cytokine TGF- $\beta$, the anti-fibrotic strategy may be (1) to antagonize TGF- $\beta$ and its signaling pathway, (2) to counteract TGF- $\beta$ or (3) to enhance the function of I-smads.

\section{(1) Block TGF- $\beta$ signaling}

Several studies have reported the remarkable effects of TGF- $\beta$ neutralizing antibodies on diabetic glomerulosclerosis. ${ }^{102,103}$ The overexpression of TGF- $\beta$-binding peptide, which keeps TGF- $\beta$ in its latent form, has also been shown to inhibit tissue fibrosis. ${ }^{104,105}$ This evidence indicates that blocking the TGF- $\beta$ signaling pathway may be an essential therapy for tissue fibrosis.

The profibrotic TGF- $\beta$ signaling pathway transduces primarily through R-smads, smad2 or smad3. Recently, smad2 and smad3 have been shown to have distinct roles in kidney fibrosis. Smad3 appears to mediate renal fibrosis, whereas smad2 antagonizes the profibrotic action of smad3. ${ }^{106}$ Therefore, targeting R-smads and, in particular, smad3 could be another potential strategy for treating kidney fibrosis by manipulating the TGF- $\beta$ signaling pathway. ${ }^{97}$ Pirfenidone has been shown to exhibit anti-R-smad effects, ${ }^{107}$ as well as beneficial effects on experimental renal disease ${ }^{108,109}$ diabetic kidney disease ${ }^{110}$ and focal segmental glomerulosclerosis. ${ }^{111}$

\section{(2) Counteract the TGF- $\beta$ signaling pathway}

Counteracting the profibrotic TGF- $\beta$-smad signaling pathway by targeting other pathways is another anti-fibrosis strategy. The bone morphogenetic protein-7 (BMP7) and its associated molecules are well-established anti-fibrotic molecules. Several BMP7 antagonists have demonstrated physiological significance, and several extracellular molecules have been identified that bind to BMP7, acting as agonists or antagonists in the kidney. ${ }^{112,113}$ BMP antagonists function by direct interaction with BMPs, thereby preventing BMPs from binding to their receptors. Such extracellular BMP signaling inhibitors include noggin, ${ }^{114}$ gremlin, ${ }^{115}$ CRIM1, ${ }^{116}$ DAN/cerberus, ${ }^{117}$ vertebrate chordin $^{118}$ and uterine sensitization-associated gene-1 (USAG-1). ${ }^{119}$ In contrast, Kielin/chordin-like protein (KCP) protein is an extracellular protein that enhances the activity of BMP7 by amplifying the physical interaction of BMP7 with its receptor. ${ }^{120}$

BMP7 is a member of the TGF- $\beta$ superfamily. ${ }^{121-123}$ BMP7 binds to three type I receptors, activin-like kinases (Alk) $-2,-3$ and -6 , and a 
type II receptor (BMPR-II) and exhibits distinct activities in various cell types, ${ }^{124}$ as well as anti-inflammatory and anti-apoptotic functions. ${ }^{125,126}$ The ligand-induced activation of BMP receptors exhibits intrinsic serine/threonine kinase activity that triggers the phosphorylation of R-smads. Smad 2 and smad3 are phosphorylated by type I receptors of TGF- $\beta$ and activin, whereas smad 1 , smad 5 and smad8 act downstream of the BMP type I receptors. ${ }^{124}$

Although the anti-fibrotic action of BMP-7 has been considered useful in the treatment of progressive kidney diseases, the multiple functions of BMP-7 limit its use due to the potential adverse nonanti-fibrogenic effects, such as bone formation. Recently, Sugimoto et al. ${ }^{127}$ reported that the BMP-7 receptor Alk-3 is essential for kidney tubular homeostasis, including anti-fibrosis, anti-inflammation and anti-apoptosis activity. The small molecular BMP-7 mimetic (known as THR-123), which is designed to bind directly to the Alk-3 receptor, exhibited anti-fibrotic effects and anti-apoptotic and antiinflammatory actions in five mouse models of acute and chronic kidney injury. ${ }^{127}$ Combining the THR-123 with ACE-I captopril had an additive therapeutic benefit in controlling renal fibrosis, ${ }^{127}$ which suggests that THR-123 may be an additional anti-fibrotic therapy in the conventional ACE-I-based intervention of fibrotic kidney diseases.

\section{(3) Induction of I-smads}

A final strategy for anti-TGF- $\beta$ signaling and anti-fibrosis therapy is to enhance the activity of I-smads. Gene transfer to induce smad7, an I-smad, can prevent diabetic glomerulosclerosis by inhibition of the renal TGF- $\beta /$ smad signaling pathway. ${ }^{128}$ There is as yet no such molecule with which to target I-smads, but this potential therapy may lie in the function of the ACE inhibition-associated rise in the antifibrotic peptide $N$-acetyl-seryl-aspartyl-lysyl-proline (AcSDKP). ${ }^{100}$

AcSDKP, a natural inhibitor of hematopoietic stem cell proliferation, is a tetrapeptide originally isolated from fetal calf bone marrow $^{129}$ and has emerged as an anti-fibrotic molecule. Although the details of the endogenous AcSDKP production pathway are not yet clear, the available evidence suggests that thymosin $\beta 4$ (TR4) is the most likely candidate precursor of AcSDKP. ${ }^{130,131}$ AcSDKP is the $\mathrm{N}$-terminal sequence of T $\beta 4$. Prolyl oligopeptidase may be responsible for the formation of AcSDKP, and prolyl oligopeptidase inhibitors may block the formation of AcSDKP from T $\beta 4 .^{100,132} \mathrm{~T} \beta 4$ also exhibits extracellular organ-protective functions that are associated with anti-fibrosis and enhanced angiogenesis, which are partially mediated by the accumulation of AcSDKP. ${ }^{133}$

AcSDKP is a substrate of the ACE N-terminal catalytic domain and is hydrolyzed in the presence of ACE. The plasma levels of AcSDKP are minimal under normal conditions, whereas ACE-I leads to a fivefold increase in the concentration of AcSDKP. ${ }^{134}$ AcSDKP suppresses the proliferation of human mesangial cells ${ }^{135}$ and renal fibroblasts, ${ }^{136}$ and the collagen deposition in mouse cardiac fibroblasts. ${ }^{137}$ AcSDKP restored glomerular sclerosis and renal fibrosis in hypertensive rat models and diabetic and non-diabetic kidney disease models without altering blood pressure. ${ }^{138,139}$ The incubation of human mesangial cells in the presence of AcSDKP leads to the cytoplasmic mobilization of smad7 in the absence of TGF $\beta$ stimulation. ${ }^{140}$ The smad7 level increases in vivo following AcSDKP administration, supporting the smad7 mediated anti-TGF- $\beta$ effects of AcSDKP. ${ }^{141,142}$ Given that AcSDKP is increased by the inhibition of ACE, AcSDKP might have an important role in the renoprotective effects of ACE-I. ${ }^{100}$ This evidence also suggests that the potential antiTGF- $\beta$ effects of AcSDKP by I-smad may provide a new therapeutic candidate for progressive kidney fibrosis. ${ }^{100}$

\section{CONCLUSION}

In almost every country, the proportion of people over 60 years of age is increasing much faster than any other age group as a result of both longer life expectancy and declining fertility rates. Functional deficiencies in the kidney may be associated with health problems in multiple organs, and therefore, the prevention of kidney aging may be an appropriate approach for combating age-related diseases (Figure 1). Aging kidneys are good candidates for such an intervention, and the aging process in kidneys could be preventable (Figure 1).

\section{CONFLICT OF INTEREST}

The authors declare no conflict of interest.

\section{ACKNOWLEDGEMENTS}

KK, MK and DK are currently supported by grants from the Japan Society for the Promotion of Science and several foundations grants.

1 Rose MR. Evolutionary Biology of Aging. Oxford University Press, New York, 1991.

2 Zhou XJ, Rakheja D, Yu X, Saxena R, Vaziri ND, Silva FG. The aging kidney. Kidney Int 2008; 74: 710-720.

3 Epstein M. Aging and the kidney. J Am Soc Nephrol 1996; 7: 1106-1122.

4 Hoy WE, Douglas-Denton RN, Hughson MD, Cass A, Johnson K, Bertram JF. A stereological study of glomerular number and volume: preliminary findings in a multiracial study of kidneys at autopsy. Kidney Int Supp/ 2003: S31-S37.

5 Anderson S, Brenner BM. Effects of aging on the renal glomerulus. Am J Med 1986; 80: 435-442.

6 Thomas SE, Anderson S, Gordon KL, Oyama TT, Shankland SJ, Johnson RJ. Tubulointerstitial disease in aging: evidence for underlying peritubular capillary damage, a potential role for renal ischemia. J Am Soc Nephrol 1998; 9: 231-242.

7 Nyengaard JR, Bendtsen TF. Glomerular number and size in relation to age, kidney weight, and body surface in normal man. Anat Rec 1992; 232: 194-201.

8 Lindeman RD, Tobin J, Shock NW. Longitudinal studies on the rate of decline in renal function with age. J Am Geriatr Soc 1985; 33: 278-285.

9 Lin SJ, Defossez PA, Guarente L. Requirement of NAD and SIR2 for life-span extension by calorie restriction in Saccharomyces cerevisiae. Science 2000; 289: 2126-2128.

10 Kuro-o M, Matsumura $Y$, Aizawa $H$, Kawaguchi $H$, Suga $T$, Utsugi T, Ohyama $Y$, Kurabayashi M, Kaname T, Kume E, Iwasaki H, Iida A, Shiraki-lida T, Nishikawa S, Nagai R, Nabeshima YI. Mutation of the mouse klotho gene leads to a syndrome resembling ageing. Nature 1997: 390: 45-51.

11 Fuiano G, Sund S, Mazza G, Rosa M, Caglioti A, Gallo G, Natale G, Andreucci M, Memoli B, De Nicola L, Conte G. Renal hemodynamic response to maximal vasodilating stimulus in healthy older subjects. Kidney Int 2001; 59: 1052-1058.

12 Rowe JW, Andres R, Tobin JD, Norris AH, Shock NW. The effect of age on creatinine clearance in men: a cross-sectional and longitudinal study. J Gerontol 1976; 31: 155-163.

13 Lindeman RD. Is the decline in renal function with normal aging inevitable? Geriatr Nephrol Urol 1998; 8: 7-9.

14 Miller M. Hormonal aspects of fluid and sodium balance in the elderly. Endocrinol Metab Clin North Am 1995; 24: 233-253.

15 Ungar A, Cristofari C, Torrini M, Di Serio C, Cantini C, Vallotti B, La Cava G, Castellani $\mathrm{S}$, Masotti G. Changes in renal autacoids in aged human hypertensives. J Physiol Pharmacol 2000; 51(Pt 1): 619-630

16 Terragno NA, Terragno DA, McGiff JC. Contribution of prostaglandins to the renal circulation in conscious, anesthetized, and laparotomized dogs. Circ Res 1977; 40: 590-595.

17 Esposito C, Plati A, Mazzullo T, Fasoli G, De Mauri A, Grosjean F, Mangione F, Castoldi F, Serpieri N, Cornacchia F, Dal Canton A. Renal function and functional reserve in healthy elderly individuals. J Nephrol 2007; 20: 617-625.

18 Field TS, Gurwitz JH, Glynn RJ, Salive ME, Gaziano JM, Taylor JO, Hennekens CH. The renal effects of nonsteroidal anti-inflammatory drugs in older people: findings from the Established Populations for Epidemiologic Studies of the Elderly. J Am Geriatr Soc 1999; 47: 507-511.

19 Whelton A. Nephrotoxicity of nonsteroidal anti-inflammatory drugs: physiologic foundations and clinical implications. Am J Med 1999; 106: 13S-24S.

20 Mulkerrin E, Epstein FH, Clark BA. Reduced renal response to low-dose dopamine infusion in the elderly. J Gerontol A Biol Sci Med Sci 1995; 50: M271-M275.

21 Morrissey PE, Yango AF. Renal transplantation: older recipients and donors. Clin Geriatr Med 2006; 22: 687-707.

22 Musch W, Verfaillie L, Decaux G. Age-related increase in plasma urea level and decrease in fractional urea excretion: clinical application in the syndrome of inappropriate secretion of antidiuretic hormone. Clin J Am Soc Nephrol 2006; 1: 909-914. 
23 Giannelli SV, Patel KV, Windham BG, Pizzarelli F, Ferrucci L, Guralnik JM. Magnitude of underascertainment of impaired kidney function in older adults with normal serum creatinine. J Am Geriatr Soc 2007; 55: 816-823.

24 Epstein M, Hollenberg NK. Age as a determinant of renal sodium conservation in normal man. J Lab Clin Med 1976; 87: 411-417.

25 Wang $\mathrm{H}$, Zhang $\mathrm{M}$, Wang $\mathrm{H}$. Renal sodium transport in heathy elderly and elderly hypertension. Geriatr Nephrol Urol 1996; 6: 13-19.

26 Perazella MA, Mahnensmith RL. Hyperkalemia in the elderly: drugs exacerbate impaired potassium homeostasis. J Gen Intern Med 1997; 12: 646-656.

27 Rowe JW, Shock NW, DeFronzo RA. The influence of age on the renal response to water deprivation in man. Nephron 1976; 17: 270-278.

28 Sands JM. Urine-concentrating ability in the aging kidney. Sci Aging Knowledge Environ 2003; 2003: PE15.

29 EIDesoky ES. Pharmacokinetic-pharmacodynamic crisis in the elderly. Am J Ther 2007; 14: 488-498.

30 Toprak O. Risk markers for contrast-induced nephropathy. Am J Med Sci 2007; 334: 283-290.

31 Pucelikova T, Dangas G, Mehran R. Contrast-induced nephropathy. Catheter Cardiovasc Interv 2008; 71: 62-72

32 Schmitt R, Cantley LG. The impact of aging on kidney repair. Am J Physiol Renal Physiol 2008; 294: F1265-F1272.

33 Eisenstaedt R, Penninx BW, Woodman RC. Anemia in the elderly: current understanding and emerging concepts. Blood Rev 2006; 20: 213-226.

34 Ble A, Fink JC, Woodman RC, Klausner MA, Windham BG, Guralnik JM, Ferrucci L. Renal function, erythropoietin, and anemia of older persons: the InCHIANTI study. Arch Intern Med 2005; 165: 2222-2227.

35 Ershler WB, Sheng S, McKelvey J, Artz AS, Denduluri N, Tecson J, Taub DD, Brant LJ, Ferrucci L, Longo DL. Serum erythropoietin and aging: a longitudinal analysis. J Am Geriatr Soc 2005; 53: 1360-1365.

36 Carpenter MA, Kendall RG, O'Brien AE, Chapman C, Sebastian JP, Belfield PW, Norfolk DR. Reduced erythropoietin response to anaemia in elderly patients with normocytic anaemia. Eur J Haematol 1992; 49: 119-121.

37 Ferrucci L, Guralnik JM, Bandinelli S, Semba RD, Lauretani F, Corsi A, Ruggiero C Ershler WB, Longo DL. Unexplained anaemia in older persons is characterised by low erythropoietin and low levels of pro-inflammatory markers. Br J Haematol 2007; 136 849-855.

38 Kario K, Matsuo T, Kodama K, Nakao K, Asada R. Reduced erythropoietin secretion in senile anemia. Am J Hematol 1992; 41: 252-257.

39 Gallagher JC, Rapuri P, Smith L. Falls are associated with decreased renal function and insufficient calcitriol production by the kidney. J Steroid Biochem Mol Biol 2007 103: 610-613.

40 Dukas L, Schacht E, Stahelin HB. In elderly men and women treated for osteoporosis a low creatinine clearance of $<65 \mathrm{ml} / \mathrm{min}$ is a risk factor for falls and fractures. Osteoporos Int 2005; 16: 1683-1690.

41 Duckworth WC, Bennett RG, Hamel FG. Insulin degradation: progress and potential. Endocr Rev 1998; 19: 608-624.

42 Akmal M, Massry SG, Goldstein DA, Fanti P, Weisz A, DeFronzo RA. Role of parathyroid hormone in the glucose intolerance of chronic renal failure. J Clin Invest 1985; 75: 1037-1044.

43 Massry SG, Fadda GZ, Zhou XJ, Chandrasoma P, Cheng L, Filburn CR. Impaired insulin secretion of aging: role of renal failure and hyperparathyroidism. Kidney Int 1991; 40: 662-667.

44 Basu R, Breda E, Oberg AL, Powell CC, Dalla Man C, Basu A, Vittone JL, Klee GG, Arora P, Jensen MD, Toffolo G, Cobelli C, Rizza RA. Mechanisms of the age-associated deterioration in glucose tolerance: contribution of alterations in insulin secretion, action, and clearance. Diabetes 2003; 52: 1738-1748.

45 Kosch M, Barenbrock M, Kisters K, Rahn KH, Hausberg M. Relationship between muscle sympathetic nerve activity and large artery mechanical vessel wall properties in renal transplant patients. J Hypertens 2002; 20: 501-508.

46 Grassi G, Calhoun DA. Sympathetic-vascular interactions: further evidence in kidney transplantation. J Hypertens 2002; 20: 379-381.

47 Zhou XJ, Saxena R, Liu Z, Vaziri ND, Silva FG. Renal senescence in 2008: progress and challenges. Int Urol Nephrol 2008; 40: 823-839.

48 Johnson S, Rishi R, Andone A, Khawandi W, Al-Said J, Gletsu-Miller N, Lin E, Baumgarten DA, O'Neill WC. Determinants and functional significance of renal parenchymal volume in adults. Clin J Am Soc Nephrol 2011; 6: 70-76.

49 Herts BR, Sharma N, Lieber M, Freire M, Goldfarb DA, Poggio ED. Estimating glomerular filtration rate in kidney donors: a model constructed with renal volume measurements from donor CT scans. Radiology 2009; 252: 109-116.

50 Jeon HG, Lee SR, Joo DJ, Oh YT, Kim MS, Kim YS, Yang SC, Han WK. Predictors of kidney volume change and delayed kidney function recovery after donor nephrectomy. J Urol 2010; 184: 1057-1063.

51 Rule AD, Amer H, Cornell LD, Taler SJ, Cosio FG, Kremers WK, Textor SC, Stegall MD. The association between age and nephrosclerosis on renal biopsy among healthy adults. Ann Intern Med 2010; 152: 561-567.

52 Goyal VK. Changes with age in the human kidney. Exp Gerontol 1982; 17: 321-331.

53 Abdi R, Slakey D, Kittur D, Racusen LC. Heterogeneity of glomerular size in normal donor kidneys: impact of race. Am J Kidney Dis 1998; 32: 43-46.

54 McLachlan MS. The ageing kidney. Lancet 1978; 2: 143-145.

55 Rule AD, Semret MH, Amer H, Cornell LD, Taler SJ, Lieske JC, Melton 3rd LJ, Stegall MD, Textor SC, Kremers WK, Lerman LO. Association of kidney function and metabolic risk factors with density of glomeruli on renal biopsy samples from living donors. Mayo Clin Proc 2011; 86: 282-290.
56 Zheng F, Plati AR, Potier M, Schulman Y, Berho M, Banerjee A, Leclercq B, Zisman A Striker LJ, Striker GE. Resistance to glomerulosclerosis in B6 mice disappears after menopause. Am J Pathol 2003; 162: 1339-1348.

57 Bolton WK, Sturgill BC. Spontaneous glomerular sclerosis in aging Sprague-Dawley rats. II. Ultrastructural studies. Am J Pathol 1980; 98: 339-356.

58 Wiggins JE. Aging in the Glomerulus. J Gerontol A Biol Sci Med Sci. (e-pub ahead of print 25 July 2012; doi:10.1093/gerona/gls157).

59 Stojanović V, Čukuranović R, Jovanović I, Vasović L, Vlajković S, Ugrenović S, Pavlović S, Dimitra L. The quantification of glomerular endothelial and mesangial cells during the human aging. Acta Fac Med Naiss 2004; 21: 65-71.

60 Wiggins JE, Goyal M, Sanden SK, Wharram BL, Shedden KA, Misek DE, Kuick RD, Wiggins RC. Podocyte hypertrophy, 'adaptation,' and 'decompensation' associated with glomerular enlargement and glomerulosclerosis in the aging rat: prevention by calorie restriction. J Am Soc Nephrol 2005; 16: 2953-2966.

61 Ortmann J, Amann K, Brandes RP, Kretzler M, Munter K, Parekh N, Traupe T, Lange M, Lattmann T, Barton M. Role of podocytes for reversal of glomerulosclerosis and proteinuria in the aging kidney after endothelin inhibition. Hypertension 2004; 44 974-981.

62 Takazakura E, Sawabu N, Handa A, Takada A, Shinoda A, Takeuchi J. Intrarena vascular changes with age and disease. Kidney Int 1972; 2: 224-230.

63 Tracy RE, Ishii T. What is 'nephrosclerosis'? Lessons from the US, Japan, and Mexico. Nephrol Dial Transplant 2000; 15: 1357-1366

64 Tracy RE, Parra D, Eisaguirre W, Torres Balanza RA. Influence of arteriolar hyalinization on arterial intimal fibroplasia in the renal cortex of subjects in the United States, Peru, and Bolivia, applicable also to other populations. Am J Hypertens 2002; 15: 1064-1073.

65 Darmady EM, Offer J, Woodhouse MA. The parameters of the ageing kidney. J Pathol 1973; 109: 195-207.

66 Baert L, Steg A. Is the diverticulum of the distal and collecting tubules a preliminary stage of the simple cyst in the adult? J Urol 1977; 118: 707-710.

67 Tanaka T, Kato H, Kojima I, Ohse T, Son D, Tawakami T, Yatagawa T, Inagi R, Fujita T, Nangaku M. Hypoxia and expression of hypoxia-inducible factor in the aging kidney. J Gerontol A Biol Sci Med Sci 2006; 61: 795-805.

68 Semenza GL. Hypoxia-inducible factor 1: master regulator of 02 homeostasis. Curr Opin Genet Dev 1998; 8: 588-594.

69 Nangaku M, Inagi R, Miyata T, Fujita T. Hypoxia and hypoxia-inducible factor in rena disease. Nephron Exp Nephrol 2008; 110: e1-e7.

70 Kaelin WG. Von Hippel-Lindau disease. Annu Rev Pathol 2007; 2: 145-173.

71 Kimura K, Iwano M, Higgins DF, Yamaguchi Y, Nakatani K, Harada K, Kubo A, Akai Y, Rankin EB, Neilson EG, Haase VH, Saito Y. Stable expression of HIF-1alpha in tubular epithelial cells promotes interstitial fibrosis. Am J Physiol Renal Physiol 2008; 295: F1023-F1029.

72 Higgins DF, Kimura K, Bernhardt WM, Shrimanker N, Akai Y, Hohenstein B, Saito Y Johnson RS, Kretzler M, Cohen CD, Eckardt KU, Iwano M, Haase VH. Hypoxia promotes fibrogenesis in vivo via HIF-1 stimulation of epithelial-to-mesenchymal transition. J Clin Invest 2007; 117: 3810-3820.

73 Choudhury D, Levi M. Kidney aging-inevitable or preventable? Nat Rev Nephrol 2011; 7: 706-717.

74 Weindruch R, Naylor PH, Goldstein AL, Walford RL. Influences of aging and dietary restriction on serum thymosin alpha 1 levels in mice. J Gerontol 1988; 43 B40-B42.

75 Colman RJ, Anderson RM, Johnson SC, Kastman EK, Kosmatka KJ, Beasley TM, Allison DB, Cruzen C, Simmons HA, Kemnitz JW, Weindruch R. Caloric restriction delays disease onset and mortality in rhesus monkeys. Science 2009; 325 201-204.

76 Liang F, Kume S, Koya D. SIRT1 and insulin resistance. Nat Rev Endocrinol 2009; 5 : 367-373.

77 Cohen HY, Miller C, Bitterman KJ, Wall NR, Hekking B, Kessler B, Howitz KT, Gorospe M, de Cabo R, Sinclair DA. Calorie restriction promotes mammalian cell survival by inducing the SIRT1 deacetylase. Science 2004; 305: 390-392.

78 Kume S, Uzu T, Horiike K, Chin-Kanasaki M, Isshiki K, Araki S, Sugimoto T, Haneda M, Kashiwagi A, Koya D. Calorie restriction enhances cell adaptation to hypoxia through Sirt1-dependent mitochondrial autophagy in mouse aged kidney. J Clin Invest 2010; 120: 1043-1055.

79 Bordone L, Cohen D, Robinson A, Motta MC, van Veen E, Czopik A, Steele AD, Crowe H, Marmor S, Luo J, Gu W, Guarente L. SIRT1 transgenic mice show phenotypes resembling calorie restriction. Aging Cell 2007; 6: 759-767.

80 Sharma S, Anjaneyulu M, Kulkarni SK, Chopra K. Resveratrol a polyphenolic phytoalexin, attenuates diabetic nephropathy in rats. Pharmacology 2006; 76: 69-75.

81 Tikoo K, Singh K, Kabra D, Sharma V, Gaikwad A. Change in histone H3 phosphorylation, MAP kinase p38, SIR 2 and p53 expression by resveratrol in preventing streptozotocin induced type I diabetic nephropathy. Free Radic Res 2008 42: 397-404

82 Ding DF, You N, Wu XM, Xu JR, Hu AP, Ye XL, Zhu Q, Jiang XQ, Miao H, Liu C, Lu YB. Resveratrol attenuates renal hypertrophy in early-stage diabetes by activating AMPK. Am J Nephrol 2010; 31: 363-374.

83 Kitada M, Kume S, Imaizumi N, Koya D. Resveratrol improves oxidative stress and protects against diabetic nephropathy through normalization of Mn-SOD dysfunction in AMPK/SIRT1-independent pathway. Diabetes 2011; 60: 634-643.

84 Dioum EM, Chen R, Alexander MS, Zhang Q, Hogg RT, Gerard RD, Garcia JA Regulation of hypoxia-inducible factor 2alpha signaling by the stress-responsive deacetylase sirtuin 1. Science 2009; 324: 1289-1293. 
85 Rodgers JT, Lerin C, Haas W, Gygi SP, Spiegelman BM, Puigserver P. Nutrient control of glucose homeostasis through a complex of PGC-1alpha and SIRT1. Nature 2005; 434: 113-118.

86 Boily G, Seifert EL, Bevilacqua L, He XH, Sabourin G, Estey C, Moffat C, Crawford S, Saliba S, Jardine K, Xuan J, Evans M, Harper ME, McBurney MW. SirT1 regulates energy metabolism and response to caloric restriction in mice. PLoS One 2008; 3: e1759.

87 Jiang T, Wang XX, Scherzer P, Wilson P, Tallman J, Takahashi H, Li J, Iwahashi M, Sutherland $E$, Arend $L$, Levi $M$. Farnesoid $X$ receptor modulates renal lipid metabolism, fibrosis, and diabetic nephropathy. Diabetes 2007; 56: 2485-2493.

88 Wang XX, Jiang T, Shen Y, Adorini L, Pruzanski M, Gonzalez FJ, Scherzer P, Lewis L, Miyazaki-Anzai $S$, Levi $M$. The farnesoid $X$ receptor modulates renal lipid metabolism and diet-induced renal inflammation, fibrosis, and proteinuria. Am J Physiol Renal Physiol 2009; 297: F1587-F1596.

89 Li X, Zhang S, Blander G, Tse JG, Krieger M, Guarente L. SIRT1 deacetylates and positively regulates the nuclear receptor LXR. Mol Cell 2007; 28: 91-106.

90 Kemper JK, Xiao Z, Ponugoti B, Miao J, Fang S, Kanamaluru D, Tsang S, Wu SY, Chiang CM, Veenstra TD. FXR acetylation is normally dynamically regulated by $\mathrm{p} 300$ and SIRT1 but constitutively elevated in metabolic disease states. Cell Metab 2009; 10: 392-404.

91 Kurosu H, Yamamoto M, Clark JD, Pastor JV, Nandi A, Gurnani P, McGuinness OP, Chikuda H, Yamaguchi M, Kawaguchi H, Shimomura I, Takayama Y, Herz J, Kahn CR, Rosenblatt KP, Kuro-o M. Suppression of aging in mice by the hormone Klotho. Science 2005; 309: 1829-1833.

92 Kuro-o M. Klotho and the aging process. Korean J Intern Med 2011; 26: 113-122.

93 Kuro-o M. A potential link between phosphate and aging-lessons from Klothodeficient mice. Mech Ageing Dev 2010; 131: 270-275.

94 Stenvinkel P. Chronic kidney disease: a public health priority and harbinger of premature cardiovascular disease. J Intern Med 2010; 268: 456-467.

95 Kuro OM. Klotho in health and disease. Curr Opin Nephrol Hypertens 2012; 21 : 362-368.

96 Wolf M. Update on fibroblast growth factor 23 in chronic kidney disease. Kidney Int 2012; 82: 737-747.

97 Lan HY. Diverse roles of TGF-beta/Smads in renal fibrosis and inflammation. Int J Biol Sci 2011; 7: 1056-1067.

98 Border WA, Noble NA. Transforming growth factor beta in tissue fibrosis. N Engl J Med 1994; 331: 1286-1292.

99 Miyazono KTGF. beta signaling by Smad proteins. Cytokine Growth Factor Rev 2000; 11: 15-22.

100 Kanasaki M, Nagai T, Kitada M, Koya D, Kanasaki K. Elevation of the anti-fibrotic peptide $\mathrm{N}$-acetyl-seryl-aspartyl-lysyl-proline: a blood pressure-independent beneficial effect of angiotensin I-converting enzyme inhibitors. Fibrogenesis Tissue Repair $2011 ; 4: 25$

101 Nakao A, Afrakhte M, Moren A, Nakayama T, Christian JL, Heuchel R, Itoh S, Kawabata M, Heldin NE, Heldin CH, ten Dijke P. Identification of Smad7, a TGFbetainducible antagonist of TGF-beta signalling. Nature 1997; 389: 631-635.

102 Ziyadeh FN, Hoffman BB, Han DC, Iglesias-De La Cruz MC, Hong SW, Isono M, Chen $S$, McGowan TA, Sharma K. Long-term prevention of renal insufficiency, excess matrix gene expression, and glomerular mesangial matrix expansion by treatment with monoclonal antitransforming growth factor-beta antibody in $\mathrm{db} / \mathrm{db}$ diabetic mice. Proc Natl Acad Sci USA 2000; 97: 8015-8020.

103 Riser BL, Denichilo M, Cortes P, Baker C, Grondin JM, Yee J, Narins RG. Regulation of connective tissue growth factor activity in cultured rat mesangial cells and its expression in experimental diabetic glomerulosclerosis. J Am Soc Nephrol 2000; 11 25-38.

104 Huang XR, Chung AC, Wang XJ, Lai KN, Lan HY. Mice overexpressing latent TGF-betal are protected against renal fibrosis in obstructive kidney disease. $\mathrm{Am} J$ Physiol Renal Physiol 2008; 295: F118-F127.

105 Huang XR, Chung AC, Zhou L, Wang XJ, Lan HY. Latent TGF-betal protects against crescentic glomerulonephritis. J Am Soc Nephrol 2008; 19: 233-242.

106 Meng XM, Huang XR, Chung AC, Qin W, Shao X, Igarashi P, Ju W, Bottinger EP, Lan HY. Smad2 protects against TGF-beta/Smad3-mediated renal fibrosis. J Am Soc Nephrol 2010; 21: 1477-1487.

107 Choi K, Lee K, Ryu SW, Im M, Kook KH, Choi C. Pirfenidone inhibits transforming growth factor-betal-induced fibrogenesis by blocking nuclear translocation of Smads in human retinal pigment epithelial cell line ARPE-19. Mol Vis 2012; 18: 1010-1020.

108 RamachandraRao SP, Zhu Y, Ravasi T, McGowan TA, Toh I, Dunn SR, Okada S, Shaw MA, Sharma K. Pirfenidone is renoprotective in diabetic kidney disease. J Am Soc Nephrol 2009; 20: 1765-1775.

109 Takakuta K, Fujimori A, Chikanishi T, Tanokura A, Iwatsuki Y, Yamamoto M, Nakajima $\mathrm{H}$, Okada $\mathrm{M}$, Itoh $\mathrm{H}$. Renoprotective properties of pirfenidone in subtotally nephrectomized rats. Eur J Pharmacol 2010; 629: 118-124.

110 Sharma K, Ix JH, Mathew AV, Cho M, Pflueger A, Dunn SR, Francos B, Sharma S, Falkner B, McGowan TA, Donohue M, Ramachandrarao S, Xu R, Fervenza FC, Kopp JB. Pirfenidone for diabetic nephropathy. J Am Soc Nephrol 2011; 22: 1144-1151.

111 Cho ME, Smith DC, Branton MH, Penzak SR, Kopp JB. Pirfenidone slows renal function decline in patients with focal segmental glomerulosclerosis. Clin J Am Soc Nephrol 2007; 2: 906-913.

112 Hogan BL. Bone morphogenetic proteins: multifunctional regulators of vertebrate development. Genes Dev 1996; 10: 1580-1594.

113 Zeisberg M. Bone morphogenic protein-7 and the kidney: current concepts and open questions. Nephrol Dial Transplant 2006; 21: 568-573.
114 Groppe J, Greenwald J, Wiater E, Rodriguez-Leon J, Economides AN, Kwiatkowski W, Affolter M, Vale WW, Izpisua Belmonte JC, Choe S. Structural basis of BMP signalling inhibition by the cystine knot protein Noggin. Nature 2002; 420: 636-642.

115 Merino R, Rodriguez-Leon J, Macias D, Ganan Y, Economides AN, Hurle JM. The BMP antagonist Gremlin regulates outgrowth, chondrogenesis and programmed cell death in the developing limb. Development 1999; 126: 5515-5522.

116 Wilkinson L, Kolle G, Wen D, Piper M, Scott J, Little M. CRIM1 regulates the rate of processing and delivery of bone morphogenetic proteins to the cell surface. $J$ Biol Chem 2003; 278: 34181-34188.

117 Belo JA, Bachiller D, Agius E, Kemp C, Borges AC, Marques S, Piccolo S, De Robertis EM. Cerberus-like is a secreted BMP and nodal antagonist not essential for mouse development. Genesis 2000; 26: 265-270.

118 Piccolo S, Sasai Y, Lu B, De Robertis EM. Dorsoventral patterning in Xenopus: inhibition of ventral signals by direct binding of chordin to BMP-4. Cell 1996; 86: 589-598.

119 Yanagita M, Okuda T, Endo S, Tanaka M, Takahashi K, Sugiyama F, Kunita S, Takahashi S, Fukatsu A, Yanagisawa M, Kita T, Sakurai T. Uterine sensitizationassociated gene-1 (USAG-1), a novel BMP antagonist expressed in the kidney, accelerates tubular injury. J Clin Invest 2006; 116: 70-79.

120 Lin J, Patel SR, Cheng X, Cho EA, Levitan I, Ullenbruch M, Phan SH, Park JM, Dressler GR. Kielin/chordin-like protein, a novel enhancer of BMP signaling, attenuates renal fibrotic disease. Nat Med 2005; 11: 387-393.

121 Zeisberg EM, Tarnavski O, Zeisberg M, Dorfman AL, McMullen JR, Gustafsson E, Chandraker A, Yuan X, Pu WT, Roberts AB, Neilson EG, Sayegh MH, Izumo S, Kalluri R. Endothelial-to-mesenchymal transition contributes to cardiac fibrosis. Nat Med 2007; 13: 952-961.

122 Zeisberg M, Hanai J, Sugimoto H, Mammoto T, Charytan D, Strutz F, Kalluri R. BMP-7 counteracts TGF-beta1-induced epithelial-to-mesenchymal transition and reverses chronic renal injury. Nat Med 2003; 9: 964-968.

123 Zeisberg M, Muller GA, Kalluri R. Are there endogenous molecules that protect kidneys from injury? The case for bone morphogenic protein-7 (BMP-7). Nephrol Dial Transplant 2004; 19: 759-761.

124 Miyazono K, Maeda S, Imamura T. BMP receptor signaling: transcriptional targets, regulation of signals, and signaling cross-talk. Cytokine Growth Factor Rev 2005; 16 : 251-263.

125 Simic P, Vukicevic S. Bone morphogenetic proteins in development and homeostasis of kidney. Cytokine Growth Factor Rev 2005; 16: 299-308.

126 Simic P, Vukicevic S. Bone morphogenetic proteins: from developmental signals to tissue regeneration. Conference on bone morphogenetic proteins. EMBO Rep 2007; 8: 327-331

127 Sugimoto H, LeBleu VS, Bosukonda D, Keck P, Taduri G, Bechtel W, Okada H, Carlson Jr W, Bey P, Rusckowski M, Tampe B, Tampe D, Kanasaki K, Zeisberg M, Kalluri R. Activin-like kinase-3 activity is important for kidney regeneration and reversal of fibrosis. Nat Med 2012; 18: 396-404.

128 Ka SM, Yeh YC, Huang XR, Chao TK, Hung YJ, Yu CP, Lin TJ, Wu CC, Lan HY, Chen A Kidney-targeting Smad7 gene transfer inhibits renal TGF-beta/MAD homologue (SMAD) and nuclear factor kappaB (NF-kappaB) signalling pathways, and improves diabetic nephropathy in mice. Diabetologia 2012; 55: 509-519.

129 Lenfant M, Wdzieczak-Bakala J, Guittet E, Prome JC, Sotty D, Frindel E. Inhibitor of hematopoietic pluripotent stem cell proliferation: purification and determination of its structure. Proc Natl Acad Sci USA 1989; 86: 779-782.

130 Grillon C, Rieger K, Bakala J, Schott D, Morgat JL, Hannappel E, Voelter W, Lenfant $\mathrm{M}$. Involvement of thymosin beta 4 and endoproteinase Asp- $\mathrm{N}$ in the biosynthesis of the tetrapeptide AcSerAspLysPro a regulator of the hematopoietic system. FEBS Lett 1990; 274: 30-34.

131 Liu JM, Garcia-Alvarez MC, Bignon J, Kusinski M, Kuzdak K, Riches A, WdzieczakBakala J. Overexpression of the natural tetrapeptide acetyl-N-ser-asp-lys-pro derived from thymosin beta4 in neoplastic diseases. Ann NY Acad Sci 2010; 1194: 53-59.

132 Cavasin MA, Rhaleb NE, Yang XP, Carretero OA. Prolyl oligopeptidase is involved in release of the antifibrotic peptide Ac-SDKP. Hypertension 2004; 43: 1140-1145.

133 Smart N, Risebro CA, Melville AA, Moses K, Schwartz RJ, Chien KR, Riley PR. Thymosin beta4 induces adult epicardial progenitor mobilization and neovascularization. Nature 2007; 445: 177-182.

134 Azizi M, Rousseau A, Ezan E, Guyene TT, Michelet S, Grognet JM, Lenfant M, Corvol $\mathrm{P}$, Menard J. Acute angiotensin-converting enzyme inhibition increases the plasma level of the natural stem cell regulator $\mathrm{N}$-acetyl-seryl-aspartyl-lysyl-proline. J Clin Invest 1996; 97: 839-844.

135 Kanasaki K, Haneda M, Sugimoto T, Shibuya K, Isono M, Isshiki K, Araki S, Uzu T, Kashiwagi A, Koya D. N-acetyl-seryl-aspartyl-lysyl-proline inhibits DNA synthesis in human mesangial cells via up-regulation of cell cycle modulators. Biochem Biophys Res Commun 2006; 342: 758-765.

136 Iwamoto N, Xano HJ, Yoshioka T, Shiraga H, Nitta K, Muraki T, Ito K. Acetylseryl-aspartyl-lysyl-proline is a novel natural cell cycle regulator of renal cells. Life Sci 2000; 66: PL221-PL226.

137 Rhaleb NE, Peng H, Harding P, Tayeh M, LaPointe MC, Carretero OA. Effect of $\mathrm{N}$-acetyl-seryl-aspartyl-lysyl-proline on DNA and collagen synthesis in rat cardiac fibroblasts. Hypertension 2001; 37: 827-832.

138 Rhaleb NE, Peng H, Yang XP, Liu YH, Mehta D, Ezan E, Carretero OA. Long-term effect of $\mathrm{N}$-acetyl-seryl-aspartyl-lysyl-proline on left ventricular collagen deposition in rats with 2-kidney, 1-clip hypertension. Circulation 2001; 103: 3136-3141.

139 Peng H, Carretero OA, Raij L, Yang F, Kapke A, Rhaleb NE. Antifibrotic effects of $\mathrm{N}$-acetyl-seryl-aspartyl-Lysyl-proline on the heart and kidney in aldosterone-salt hypertensive rats. Hypertension 2001; 37(Part 2): 794-800. 
140 Kanasaki K, Koya D, Sugimoto T, Isono M, Kashiwagi A, Haneda M. N-Acetyl-seryl aspartyl-lysyl-proline inhibits TGF-beta-mediated plasminogen activator inhibitor-1 expression via inhibition of Smad pathway in human mesangial cells. J Am Soc Nephrol 2003; 14: 863-872.

141 Omata M, Taniguchi H, Koya D, Kanasaki K, Sho R, Kato Y, Kojima R, Haneda M, Inomata $\mathrm{N}$. N-acetyl-seryl-aspartyl-lysyl-proline ameliorates the progression of renal dysfunction and fibrosis in WKY rats with established anti-glomerular basement membrane nephritis. J Am Soc Nephrol 2006; 17: 674-685.

142 Lin CX, Rhaleb NE, Yang XP, Liao TD, D'Ambrosio MA, Carretero OA Prevention of aortic fibrosis by $\mathrm{N}$-acetyl-seryl-aspartyl-lysyl-proline in angiotensin II-induced hypertension. Am J Physiol Heart Circ Physiol 2008; 295 $\mathrm{H} 1253-\mathrm{H} 1261$. 